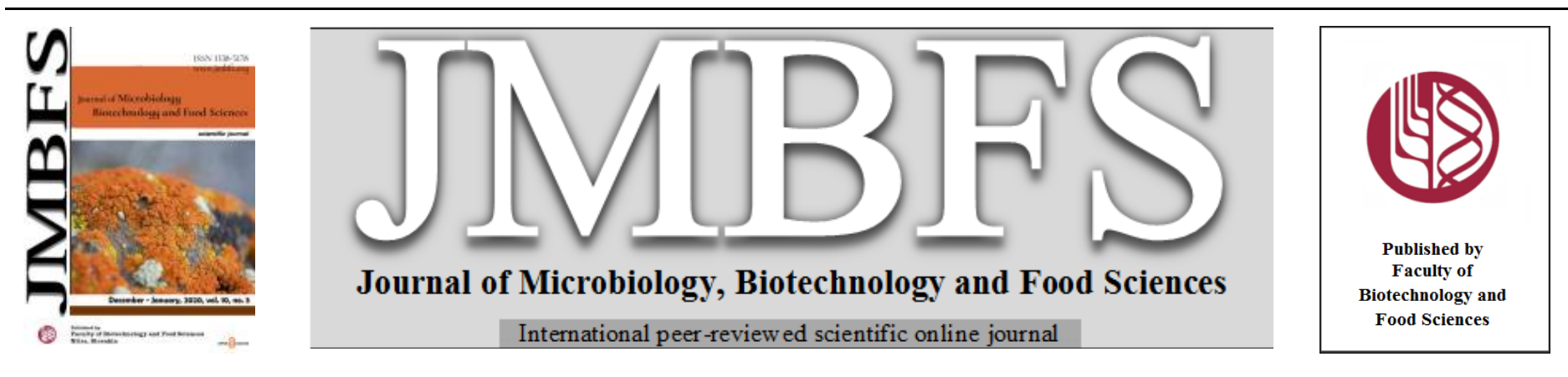

\title{
ROOT ASSOCIATED BACTERIAL ENDOPHYTES FROM POACEAE PLANTS: IDENTIFICATION, CHARACTERIZATION AND PLANT GROWTH PROMOTION
}

\author{
Janki K. Patel ${ }^{a, b^{*}}$, Rupal Agrawal ${ }^{b}$, Radhika Sidhdhapara $^{b}$ \\ $\operatorname{Address}(e s)$ : \\ ${ }^{a}$ Department of Biological Sciences, P D Patel Institute of Applied Sciences, Charotar University of Science and Technology, Changa, India. \\ ${ }^{\mathrm{b}} \mathrm{School}$ of Science, RK. University, Rajkot, Gujarat, India.
}

*Corresponding author: jankipatel.bio@charusat.ac.in

doi: $10.15414 / j m b f s .2020 .10 .3 .478-483$

\section{ARTICLE INFO}

Received 29. 3. 2020

Revised 23. 9. 2020

Accepted 24. 9. 2020

Published 1. 12. 2020

Regular article

open 2 access

\begin{abstract}
Diazotrophic endophytic bacteria contribute to the plant growth using various plant growth promoting traits as well as by inducing the plant defence mechanism upon pathogen attack. Aim of the present study was to isolate true diazotrophic endophytic bacteria from the total diazotrophic bacterial community of wheat and pearl-millet plants. Further, these isolates were evaluated for their potential of plant growth promotion by in vitro and in vivo experiments. We isolated total three diazotrophic endophytic bacteria based on their growth after repetitive subculturing on nitrogen free medium. Molecular characterization of all three isolates showed affiliation to the genera Agrobacterium, Pseudomonas and Brevundimonas. In vitro analysis of plant growth promoting traits showed positive result for indole acetic acid (IAA) production, cellulase and protease activity. The IAA production is found between the ranges of 98 to $113 \mu \mathrm{g} \mathrm{ml}^{-1}$. All the endophytic bacterial isolates showed the PCR amplification of NifH gene and ammonia production. Diazotrophic endophytic bacterial isolates (PR1, JB3 and JB6) were tested for their capacity to promote the plant growth using pot experiment. All the diazotrophic endophytic bacteria differ in their plant growth promotion ability as analyzed by various plant growth parameter compared to the untreated control plants. In Pot experiment, PR1 and JB6 showed a significant difference in dry weight of root, whereas JB3 and JB6 showed the significant differences in shoot length and total nitrogen content $(\mathrm{p} \leq 0.05)$ compared to the untreated plants.
\end{abstract}

Keywords: Endophyte; Diazotrophs; Plant Growth Promotion; Heavy Metal Tolerance; Saline tolerance; Pot method

\section{INTRODUCTION}

Soil is a rich source of a diverse group of bacterial communities and diversity of these bacteria get vary according to the environmental condition such as temperature, pH and altitude etc. (Gourmelon et al., 2016; Praeg et al., 2019). Diversity of microbes is comparatively higher in the rhizosphere, but only a small portion of soil bacteria can enter inside the plant tissue and have the endophytic lifestyle (Patel and Archana 2017; Praeg et al., 2019). Moreover, there were only very small numbers of diazotrophic endophytic bacteria present in internal tissues in cereals (Gyneshwar et al., 2001; Feng et al., 2006; Peng et al., 2009; Patel and Archana 2017) and vegetables (Madhaiyan et al., 2004).

Nitrogen makes up $78 \%$ of the atmosphere but it cannot be easily accessible to the plants. However, plants can only absorb the nitrogen in the form of nitrate and ammonium (Santi et al., 2013; Puri et al., 2018). Biological nitrogen fixation is carried out mainly by two processes lightning and microbes. The increase in human population cannot sustain on these processes of nitrogen fixation for food production. To fulfil the requirement of food production requires the chemical synthesis of nitrogen which is carried out by the HaberBosch process. This process consumes a large amount of fossil fuel to generate high temperature and pressure for the synthesis of nitrogen fertilizer (Puri et al., 2018). Besides of that, a large portion of the applied synthetic nitrogen fertilizer does not utilize by the plants and ultimately it ends up into the groundwater contamination and nitrate is known for its carcinogenic activity during animal studies (Ward 2009). Thus, it would be crucial to establish the plants symbiotic association with the diazotrophic organism for sustainable crop production. Moreover, recent studies now more focused on the isolation of symbiotic nitrogen fixing bacteria as it fixes more amount of nitrogen compared to the freeliving nitrogen fixer.

Endophytic bacteria define as the microbes which once in their life cycle reside inside the internal tissues of the plants and can be re-isolated upon re-inoculation into the plant system known as a true endophyte (Reinhold-Hurek and Hurek 1998; Hardoim et al., 2015). Nowadays, numbers of endophytic bacteria have been isolated from a variety of cereal crops. In this, diazotrophic bacteria have been reported from rice (Ladha and Barraquio 1997; Gyaneshwar et al., 2001;
Prakamhang et al., 2009; Ji et al., 2014; Patel and Archana 2017), maize (Baldani et al., 1986; Estrada et al., 2002; Patel and Archana 2017), wheat (Silveira et al., 2016; Patel and Archana 2017), sorghum (Mareque et al., 2015; Patel and Archana 2017) and pearl millet (Patel and Archana 2017). These studies indicate the nitrogen fixation is not only limited to the legumerhizobia but it also associated with cereal plants. The important diazotrophic genera include the Azoarcus, Burkholderia, Bradyrhizobium, Gluconoacetobacter, Methylobacterium, Herbaspirillum, Serratia, Arthrobacter, Microbacterium, Streptomyces, Azospirillum, Sinorhizobium, Pseudomonas, Klebsiella, Ralstonia, Staphylococcus, Acinetobacter, Achromobacter, and Bacillus (Rosenblueth and Martínez-Romero 2006; Patel and Archana 2017). The most efficient nitrogen fixing Rhizobium spp. has been isolated from above as well as below-ground plant parts as endosymbiont (Yanni et al., 1997; Chi et al., 2005; Prayitno and Rolfe 2010; Patel and Archana 2017).

The present study was aimed to characterize the diazotrophic endophytic bacteria from wheat and pearl millet by culture dependent method. Furthermore, evaluate the plant growth promoting traits by in vitro analysis. This knowledge was utilized to study its ability to promote the plant growth promotion under in vivo condition.

\section{MATERIALS AND METHODS}

\section{Isolation of diazotrophic endophytic bacteria}

Healthy wheat and Pearl millet plant samples were collected from an agricultura field of Anand, Gujarat, India. Plant samples were washed under running tap water to remove residues attached on the surface. Further, surface sterilization was carried out using the following process: $70 \%$ ethanol for 1 minute, $2 \%$ sodium hypochlorite for 1 minute and rinsed five times in sterile distilled water. Finally the plants were plated on Luria Bertani (LB) agar to ensure that complete surface sterilization has occurred. The root parts of wheat and pearl millet plants were macerated in $\mathrm{N}$-Saline $(0.9 \%)$. The tissue extract obtained was inoculated into semi-solid nitrogen free base $(\mathrm{NFb})$ medium, incubated at $30^{\circ} \mathrm{C}$ for 7 days and further transferred to a semi-solid NFb medium was given for another 7 days. 
The consecutive three transfers were given after $15 \mathrm{~d}$ of the growth period in $\mathrm{NFb}$ medium. After several transfers, root samples were plated on $\mathrm{NFb}$ medium and incubated the plate till $7 \mathrm{~d}$. Bacterial colonies further purified by repetitive subculturing on NFb medium (Patel and Archana 2017). Colony morphology of pure culture was studied on Jensen's agar plate (Himedia, India).

\section{Biochemical Characterization}

Initial characterization of diazotrophic endophytic bacteria was carried out by gram-staining, MR-VP test, indole test, motility, oxidase production, triple sugar iron test, citrate utilization, starch hydrolysis, urea hydrolysis, gelatin hydrolysis and casein hydrolysis as mentioned in the Bergey's Manual of Determinative Bacteriology (Holt et al., 1994). Carbohydrate utilization test was carried out using 35 different sugar combination of HiCarbo kit (Himedia, India)

\section{Identification of diazotrophic endophytic bacteria by 16s rRNA sequencing}

Identification of diazotrophic endophytic bacteria was carried out using $16 \mathrm{~s}$ rRNA sequencing. DNA extraction was performed from isolates as described in Sambrook and Russell (2001). 16s rRNA region was amplified using universal eubacterial primer $8 \mathrm{~F}$ and $1492 \mathrm{R}$. The $25 \mu \mathrm{l}$ of reaction mixture consisted of 50 ng DNA template, $0.5 \mu \mathrm{l}$ of $10 \mu \mathrm{M}$ each primer, $1 \mu \mathrm{l}$ of $2.5 \mathrm{mM}$ dNTPs each, 0.5 $\mathrm{U}$ Taq DNA polymerase and $2.5 \mu \mathrm{l} 10 \mathrm{X}$ Taq buffer. PCR reaction was consisting of initial denaturation at $95^{\circ} \mathrm{C}$ for 5 minutes, followed by 30 cycles consisting of initial denaturation at $94{ }^{\circ} \mathrm{C}$ for $45 \mathrm{~s}$, annealing temperature $55^{\circ} \mathrm{C}$ for $45 \mathrm{~s}$, elongation $72{ }^{\circ} \mathrm{C}$ for 1.5 minutes, final elongation carried out at $72{ }^{\circ} \mathrm{C}$ for $10 \mathrm{~min}$ (Patel and Archana 2017). PCR product was resolved on $1 \%$ agarose gel. 16 rRNA PCR amplified products were subjected to Sanger sequencing (Thermo Scientific, ABI, United States). The sequences were subjected to the Sequence Match tool at the Ribosomal Database Project (RDP) (Wang et al., 2007) and Nucleotide BLASTn in NCBI database (Altschul et al., 1990). The phylogenetic tree was constructed by the neighbor-joining algorithm with the p-distance method of MEGA 10 (Kumar et al., 2018).

\section{Amplification of $\mathrm{NifH}$ gene}

Nitrogen fixation ability of the diazotrophic endophytic bacteria was confirmed by NifH gene (dinitrogenase reductase) amplification. The PCR amplification was carried out using PolF and AQER primer (Poly et al., 2001) as in $25 \mu \mathrm{l}$ reaction mixture was prepared as described in 16rRNA gene amplification. The reaction was carried out as follow: $94{ }^{\circ} \mathrm{C}$ for $5 \mathrm{~min}$, followed by 30 cycles consisting of initial denaturation $94^{\circ} \mathrm{C}$ for 1 minute, annealing temperature $55^{\circ} \mathrm{C}$ for 45 seconds, elongation $72{ }^{\circ} \mathrm{C}$ for 1 minute, final elongation carried out at 72 ${ }^{\circ} \mathrm{C}$ for 10 minutes (Patel and Archana 2017).

\section{Plant growth promoting traits in diazotrophic endophytes}

Indole acetic acid production was observed by inoculating the pure cultures in sterile Luria- Bertani (LB) (Himedia, India) broth amended with $5 \mathrm{mM}$ of Ltryptophan and incubated at $30{ }^{\circ} \mathrm{C}$ for 48 hours under shaking condition (200 rpm). IAA production was assayed as described by Ahmad et al., (2008).

For ammonia production estimation, endophytic bacterial isolates were grown in sterile peptone broth at $30{ }^{\circ} \mathrm{C}$ for 72 hours under shaking condition. After the incubation, culture supernatant was inoculated with Nessler's reagent and observed for the formation of yellow to brown colour.

Phosphate solubilization by the isolates were observed by spot inoculation of overnight grown culture on Pikovskaya's agar (Himedia, India) plates and incubated at $30{ }^{\circ} \mathrm{C}$ for 120 hours. Isolates were observed for the zone of clearance.

All the isolates were also observed for $\mathrm{HCN}$ production as described by Patel and Archana (2017). The LB agar was amended with glycine $\left(4.4 \mathrm{~g} \mathrm{l}^{-1}\right)$. The bacterial cultures were spread on the plates and the lid of that plate contains the Whatman filter paper No. 1, saturated in a solution containing sodium carbonate $(2 \% \mathrm{w} / \mathrm{v})$ and picric acid $(0.5 \% \mathrm{v} / \mathrm{v})$. Finally, plates were sealed with parafilm and incubated at $30{ }^{\circ} \mathrm{C}$ for 120 hours. The change in the color of Whatman filter paper from yellow to orange or brown color indicated the $\mathrm{HCN}$ production. All the isolates were analyzed for dual culture test against the Bacillus subtilis (ATCC 6051), Staphylococcus aureus (ATCC 6538), Bacillus cereus (ATCC 11778), and Escherichia coli (ATCC 25922). The test culture and the diazotrophic endophytic isolates were streaked in near vicinity, incubate the plates for 24 hours and observed for the growth inhibition of the test culture.
Evaluation of diazotrophic endophytic bacteria for antibiotic and heavy metal tolerance

Diazotrophic endophytic bacterial strains were tested for their sensitivity to thirteen different antibiotics by disc diffusion method. Endophytic bacterial cultures were grown overnight in LB broth at $30{ }^{\circ} \mathrm{C}$. A $100 \mu 1$ endophytic bacterial culture inoculated on the top agar and poured on LB agar plate base and allowed to solidify. The known concentration of antibiotic discs were placed on the surface of top agar and incubated for 24 hours at $30^{\circ} \mathrm{C}$. Antibiotic discs were used in this study were Kanamycin (30 mg), Streptomycin (10 mg), Erythromycin $(15 \mathrm{mg})$, Gentamicin (10 mg), Rifampicin (5 mg), Ciproflaxin (5 $\mathrm{mg}$ ), Ampicillin (10 mg), Polymyxin-B (300 units), Tetracycline (30 mg), Chloramphenicol $(30 \mathrm{mg})$, Vancomycin $(30 \mathrm{mg})$, Methicillin $(5 \mathrm{mg})$ and Penicillin-G (10 mg) (Himedia, India).

Heavy metal tolerance of the diazotrophic endophytic bacteria was tested against lead $(\mathrm{Pb})$, magnesium $(\mathrm{Mg})$, manganese $(\mathrm{Mn})$, barium $(\mathrm{B})$, aluminium $(\mathrm{Al})$, mercury $(\mathrm{Hg})$, cerium $(\mathrm{Ce})$, Zinc $(\mathrm{Zn})$, cadmium $(\mathrm{Cd})$ and nickel $(\mathrm{Ni})$ (SRL, India). Heavy metal was added to the $\mathrm{LB}$ agar medium to the $500 \mathrm{ppm}$ concentration. All the isolates were streaked on LB agar amended with different heavy metal and incubated at $30{ }^{\circ} \mathrm{C}$ for 48 hours. A positive control was kept without heavy metal and negative control amended with heavy metal; both the plates were streaked with $E$. coli.

\section{Analysis of diazotrophic endophytic bacteria for salt tolerance}

Salt tolerance of the all the selected diazotrophic endophytic bacteria were carried out using LB agar medium amended with different salt concentration $(0.7$ $\mathrm{M}, 1.2 \mathrm{M}, 1.7 \mathrm{M}$ and $2.5 \mathrm{M}$ ). Plates were streaked and incubated at $30^{\circ} \mathrm{C}$ for 5 days and observed for the visible growth on the medium. Positive controls were kept without salt amended LB agar medium, inoculated with endophytic bacterial strains.

\section{Plant inoculation and colonization}

The diazotrophic endophytic bacteria were observed for their plant growth promoting ability under natural soil condition. Firstly, wheat seeds were surface sterilized by washing twice with normal tap water, followed with dip it in ethanol for 1 minute and further, it transferred it in $0.1 \% \mathrm{HgCl}_{2}$ solutions for 2 minutes Finally, the seeds were washed 6-7 times with sterile distilled water. These sterilized seeds were transferred to soft agar plate for germination and the plates were kept in dark for $2 \mathrm{~d}$ at $30^{\circ} \mathrm{C}$.

The germinated seedlings of the same length were selected for the pot experiments. Each pot received the $200 \mathrm{~g}$ of non-sterile soil (RK Farm, RajkotBhavnagar highway, Rajkot) and inoculated with $10^{8} \mathrm{CFU}$ for each bacterial culture in the respective pots. These pots were watered regularly with sterile distilled water and were exposed under natural daylight (approximately $12 \mathrm{~h}$ photoperiod). After 15 days of growth, plants were uprooted, surface sterilized and processed for $\mathrm{CFU} \mathrm{g} \mathrm{g}^{-1}$, shoot length, root length, wet weight of shoot and root. Total nitrogen content of the plants was measured using the micro-Kjeldahl method (Villegas et al., 1984). Pot experiments were triplicated and results were compiled.

\section{Data analysis}

The statistical analysis of the data was performed in Microsoft Excel and has been expressed in mean along with standard deviation. Variance in data was analyzed using Levene's test followed by student's t- test to determine the significance differences.

\section{RESULTS}

\section{Characterization of culturable diazotrophic endophytic bacteria}

The diazotrophic endophytic bacteria were isolated from wheat and pearl millet root parts of the plants. The tissue extract was enriched on nitrogen free medium for several times. After the enrichment, the pure culture of the diazotrophic endophytic bacteria was selected by plating the culture on $\mathrm{NFb}$ medium. Total three diazotrophic endophytic bacteria obtained from the root part of wheat and pearl-millet plants. In all the isolates, two isolates were obtained from the wheat plant while one from pearl millet. The isolates found in this study showed the colony morphology white, viscous with entire margin on Jensen's agar plate (Table 1). All three isolates were gram-negative rod shaped. 
Table 1 Colony morphology on Jensen's agar plate

\begin{tabular}{llllllll}
\hline Isolates & Size & Shape & Margin & Elevation & Pigment & Consistency & Opacity \\
\hline PR1 & Large & Round & Entire & Convex & White & Viscous & Opaque \\
JB1 & Large & Round & Entire & Convex & White & Viscous & Opaque \\
JB3 & Large & Round & Entire & Convex & White & Viscous & Opaque \\
JB6 & Large & Round & Repand & Effused & White & Viscous & Opaque \\
\hline
\end{tabular}

\section{Identification of diazotrophic endophytic isolates and phylogenetic tree}

Characterization of all the four isolates were performed firstly based on the biochemical test (Table 2). For molecular identification, 16s rRNA gene sequencing of the three isolates were analyzed in NCBI and RDP databases. All the endophytic bacterial isolates were showed the $99 \%$ alignment with a similar match in the database (Table 3). The bacterial isolates showed the affiliation to $\alpha$ and $\gamma$-Proteobacteria. The strains represent three different genera which includes Rhizobium Pseudomonas and Brevundimonas. The 16s rRNA sequences were deposited in GenBank (Accession numbers: MT197317; MT197318, KX599209). The phylogenetic tree of the endophytic isolates generated using its representative sequences obtained after the alignment in the NCBI database has been depicted in Figure. 1.

Table 2 Biochemical characterization of diazotrophic endophytic bacteria

\begin{tabular}{|c|c|c|c|c|}
\hline Sr. No. & Test & PR1 & JB3 & JB6 \\
\hline \multirow[t]{36}{*}{1} & Sugar & & & \\
\hline & Lactose & - & - & + \\
\hline & Xylose & - & - & + \\
\hline & Maltose & + & + & + \\
\hline & Fructose & + & + & + \\
\hline & Dextrose & + & + & + \\
\hline & Galactose & - & - & + \\
\hline & Raffinose & - & - & - \\
\hline & Trehalose & + & + & + \\
\hline & Melibiose & - & + & - \\
\hline & Sucrose & + & + & + \\
\hline & L-Arabinose & + & + & + \\
\hline & Mannose & + & + & + \\
\hline & Inulin & + & + & + \\
\hline & Sodium gluconate & - & - & - \\
\hline & Glycerol & + & + & + \\
\hline & Salicin & + & + & + \\
\hline & Dulcitol & - & - & - \\
\hline & Inositol & + & + & + \\
\hline & Sorbitol & + & + & + \\
\hline & Mannitol & + & + & + \\
\hline & Adonitol & - & + & - \\
\hline & Arbitol & - & + & - \\
\hline & Erythritol & - & + & - \\
\hline & $\alpha$-Methyl-D-glucoside & - & - & - \\
\hline & Rhamnose & - & - & - \\
\hline & Cellobiose & + & + & + \\
\hline & Melezitose & - & - & - \\
\hline & A-Methyl-D-Mannoside & - & - & - \\
\hline & Xylitol & - & - & - \\
\hline & ONPG & - & + & + \\
\hline & Esculin & + & + & + \\
\hline & D-Arabinose & + & + & + \\
\hline & Citrate & + & - & + \\
\hline & Malonate & + & + & + \\
\hline & Sorbose & + & + & - \\
\hline 2. & Methyl-Red (MR) & + & - & + \\
\hline 3. & Citrate utilization & + & - & + \\
\hline 4. & $\begin{array}{l}\text { Voges - Proskauer } \\
\text { (VP) }\end{array}$ & - & - & - \\
\hline 5. & Indole & - & - & + \\
\hline 6. & Starch Hydrolysis & + & - & + \\
\hline 7. & Gelatin hydrolysis & - & - & - \\
\hline 8. & Casein hydrolysis & + & + & + \\
\hline 9. & Oxidase & + & + & + \\
\hline \multirow[t]{3}{*}{10.} & TSI & & & \\
\hline & Glucose & + & + & + \\
\hline & Lactose & + & + & + \\
\hline 11 & Motility & + & + & + \\
\hline
\end{tabular}
method using the partial sequences of 16s rRNA gene of diazotrophic endophytic bacteria. The associated taxa clustered together by 1000 bootstrap analysis, which is shown next to the branches. The evolutionary distance was calculated using the p-distance method.

\section{Plant Growth promoting traits in diazotrophic endophytic bacteria}

Further, characterization of the endophytic bacteria was carried out based on their plant growth promoting ability using the in-vitro assay. The nitrogen fixation was characterized based on nifH gene amplification and the ammonia production in all the isolates. All the endophytic bacterial isolates showed positive result for nifH gene amplification and ammonia production. IAA production was positive in all the three isolates with the range of $98 \mu \mathrm{g} \mathrm{ml}^{-1}$ to $113 \mu \mathrm{g} \mathrm{ml}^{-1}$ in the presence of tryptophan as a precursor (Table 4). The highest production was obtained with Rhizobium sp. PR1 followed by other isolates. The zone of clearance was obtained around all the colonies on CMC agar plate indicated the cellulase enzyme production by all the three diazotrophic endophytic bacteria. The protease activity was obtained positive in all three isolates. All the isolates were negative for phosphate solubilization, hydrogen cyanide production and antibacterial activity after 120 hours of the incubation period (Table 4).

\section{Heavy metal and salt tolerance and antibiotic sensitivity}

The diazotrophic endophytic bacterial isolates were tested for their ability to tolerate the heavy metals. All the three isolates were showed the tolerance to lead, magnesium, manganese, barium and aluminium respectively, amended with $500 \mathrm{ppm}$ in agar plate. The sensitivity towards the various antibiotics was observed. Among the three bacterial strains, PR1 and JB3 showed resistance against the polymixin-B and JB6 showed resistance toward polymixin-B and methicillin. The salt tolerance of all the three endophytic bacterial isolates were observed up to $1.7 \mathrm{M}$ on LB agar plates amended with $\mathrm{NaCl}$.

\section{Plant growth promotion in endophytic colonized wheat plants}

Diazotrophic endophytic bacterial plant growth promotion was analyzed after 15 days of a plant growth period. The bacterial isolates were showed a significant influence on various growth parameters. The assessment of plant growth promotion was carried out in comparison with the uninoculated control plants. The dry biomass was significantly increased in the root part of the plants inoculated with isolates compared to the uninoculated plants. The total nitrogen content of the aerial part of the wheat plants were also significantly improved upon the inoculation of JB3 and JB6. The efficiency of plant growth promotion in wheat plants were significantly variable with different isolates.

\section{Endophytic colonization potential of the diazotrophs}

Endophytic colonization was determined by plate count method using Jensen's and Luria Bertani agar plate after 15 days of growth period on the polymixin-b (30 $\mu \mathrm{g} \mathrm{ml}{ }^{-1}$ ) amended plate. Total endophytic bacterial community and diazotrophic endophytic bacterial community were analyzed in the wheat plant along with the control plant. Counting was determined based on morphological similarities with isolates. The diazotrophic endophytic bacterial colonization was observed in root and shoot parts of the plants. The highest colonization of Rhizobium sp. PR1 was observed in the root part of the plant compared to the other isolates (Table 5). 
Table 3 Molecular identification of diazotrophic endophytic bacteria

\begin{tabular}{|c|c|c|c|c|c|c|c|}
\hline $\begin{array}{l}\text { Sr. } \\
\text { No. }\end{array}$ & Strain & $\begin{array}{l}\text { Accession } \\
\text { number }\end{array}$ & $\begin{array}{l}\text { Base } \\
\text { pair } \\
\text { length }\end{array}$ & Closest Sequence Match & $\begin{array}{l}\text { Sequence } \\
\text { Identity }\end{array}$ & $\begin{array}{l}\text { Source of } \\
\text { Isolation }\end{array}$ & Taxonomic group \\
\hline 1 & PR1 & KX599203 & 947 & $\begin{array}{l}\text { Rhizobium pusense strain } \\
\text { L3/4 (MT378404) }\end{array}$ & $99 \%$ & $\begin{array}{l}\text { Pearl-millet } \\
\text { plant root }\end{array}$ & $\alpha$-Proteobacteria \\
\hline 2 & JB3 & MT197318 & 1425 & $\begin{array}{l}\text { Pseudomonas gessardii } \\
\text { (KJ547711) }\end{array}$ & $99 \%$ & Wheat plant root & $\gamma$-Proteobacteria \\
\hline 3 & JB6 & MT197317 & 825 & $\begin{array}{l}\text { Brevundimonas aurantiaca } \\
\text { strain XFB-I } \\
\text { (KC429645) }\end{array}$ & $99 \%$ & & $\alpha$-Proteobacteria \\
\hline
\end{tabular}

\begin{tabular}{|c|c|c|c|c|c|c|}
\hline Bacterial strain & $\mathrm{NifH}$ gene & $\begin{array}{l}\text { IAA production } \\
\left(\mu \mathrm{g} \mathrm{ml}^{-1}\right)\end{array}$ & $\begin{array}{c}\text { Phosphate } \\
\text { solubilization }\end{array}$ & Cellulase & Protease & HCN production \\
\hline PR1 & + & $113 \pm 1.94$ & - & + & + & - \\
\hline JB3 & + & $98 \pm 3.89$ & - & + & + & - \\
\hline JB6 & + & $108 \pm 1.94$ & - & + & + & - \\
\hline
\end{tabular}

Table 5 Analysis of the effect of diazotrophic endophytic bacterial inoculation on plant growth promotion upon 15 days of plant growth period

\begin{tabular}{|c|c|c|c|c|c|c|c|c|c|}
\hline Treatment & $\begin{array}{l}\text { Shoot length } \\
(\mathrm{cm})\end{array}$ & $\begin{array}{l}\text { Root length } \\
\quad(\mathrm{cm})\end{array}$ & $\begin{array}{l}\text { Wet weight of } \\
\text { shoot }(\mathrm{g})\end{array}$ & $\begin{array}{l}\text { Wet weight } \\
\text { of root }(\mathrm{g})\end{array}$ & $\begin{array}{l}\text { Dry weight of } \\
\text { shoot }(\mathrm{g})\end{array}$ & $\begin{array}{l}\text { Dry weight of } \\
\text { root }(\mathrm{mg})\end{array}$ & $\begin{array}{c}\text { Total } \\
\text { Nitrogen } \\
\text { Content }(\%)\end{array}$ & \multicolumn{2}{|c|}{$\mathrm{CFU} \mathrm{g}^{-1}$ fresh tissue } \\
\hline Control $^{\mathrm{a}}$ & $21.53 \pm 1.10$ & $12 \pm 4.90$ & $0.16 \pm 0.01$ & $0.03 \pm 0.01$ & $0.017 \pm 0.01$ & $4.67 \pm 0.58$ & $1.12 \pm 0.35$ & - & - \\
\hline PR1 & $24.83 \pm 2.45$ & $14.87 \pm 1.33$ & $0.18 \pm 0.04$ & $0.05 \pm 0.01$ & $0.023 \pm 0.01$ & $9.33 \pm 0.58 * * *$ & $2.12 \pm 0.49$ & $2 \times 10^{4}$ & $1 \times 10^{5}$ \\
\hline JB3 & $28.10 \pm 3.38^{* *}$ & $15.33 \pm 0.49$ & $0.21 \pm 0.04$ & $0.04 \pm 0.01$ & $0.030 \pm 0.02$ & $5.67 \pm 0.58$ & $2.65 \pm 0.28^{*}$ & $7 \times 10^{4}$ & $1 \times 10^{4}$ \\
\hline JB6 & $25.60 \pm 1.65^{* *}$ & $15.73 \pm 2.41$ & $0.18 \pm 0.02$ & $0.05 \pm 0.01$ & $0.023 \pm 0.01$ & $6.67 \pm 1.15^{*}$ & $2.87 \pm 0.28^{* *}$ & $7 \times 10^{4}$ & $1 \times 10^{4}$ \\
\hline
\end{tabular}

$* \mathrm{p}<0.05, * * \mathrm{p}<0.03, * * * \mathrm{p}<0.0$

a- Control plants were not inoculated with bacterial isolates

\section{DISCUSSION}

Nitrogen fixation in cereal plants is not strong enough like in legume plants Cereal plants are the staple food around the world requires efficient nitrogen sequestration for sustainable plant growth promotion. This study was aimed to isolate the potential diazotrophic endophytic bacteria from the root part of wheat and pearl-millet plants. Further, characterization of root colonization of diazotrophic endophytic bacteria showed that only specific culturable strains can be obtained after repetitive transfer on nitrogen free medium. Combining the result of 16s rRNA sequencing and MEGA software analysis showed that, these strains belong to genera Agrobacterium, Pseudomonas and Brevundimonas. All the three diazotrophic endophytic bacteria can be represented as usual rhizosphere plant root colonizer. Similar strains have been reported as plant endophytic bacteria (Prakamhang et al., 2009; Madhaiyan et al., 2015; Patel et al., 2017). This approach allowed growing only potential diazotroph and all others get eliminated upon repetitive transfer on nitrogen free medium.

All the three strains investigated for their plant growth promoting traits such as nitrogen fixation, ammonia production, IAA production and phosphate solubilization. They were also studied for its biocontrol properties such as protease and $\mathrm{HCN}$ production. In this work, nitrogen fixation ability of isolates was confirmed by nifH gene amplification (Poly et al., 2001). All the isolates used in this study were positive for ammonia production. As in biological nitrogen fixation, the atmospheric nitrogen $\left(\mathrm{N}_{2}\right)$ converted in $\mathrm{NH}_{3}$ and $\mathrm{NH}_{4}{ }^{+}$, which can be easily taken up by plants (Meena et al., 2017). Plant growth can be directly enhanced upon the colonization of IAA producing organism. IAA induces the root elongation and formation of adventitious root leads to better absorption of water and nutrient from the rhizosphere area. All three isolates from this study showed the positive result for the IAA production, whereas the ability of IAA production differed in each case. The highest production found in Agrobacterium sp. PR1 was $113 \mu \mathrm{g} \mathrm{ml}^{-1}$. The IAA production ability of bacteria in the rhizosphere depends on the availability of precursors and uptake of microbial IAA by the plant (Arshad and Frankenberger 1991), whereas inplanta microbial production of IAA was directly accessible to the host plant. All the bacterial isolates were screened for in-vitro phosphate solubilizing ability showed a negative result. It has been reported that higher concentrations of phosphate-solubilizing bacteria are commonly found in the rhizosphere soil as compared to the non-rhizospheric soil (Reyes et al.,2012) and the secretion of organic acid in the rhizosphere area leads to solubilization of insoluble phosphate and make it available to the plants (Richardson et al., 2009). Phosphate solubilizing diversity of endophytic bacteria was less compared to the rhizosphere area (Patel et al., 2017; Solanki et al., 2018). All the isolates were negative for the HCN production, whereas all isolates positive for protease activity. The production of extracellular protease has been previously reported for its biocontrol activity against plant pathogen (Zhang et al., 2012). Besides, the cell wall degrading enzyme was also analyzed in the isolates. All the isolates were showed the positive result on CMC agar plate assay. The cell wal degrading enzymes assist the endophytes in their entry inside the internal plant tissue (Patel and Archana 2017).

Various anthropogenic activities lead to the accumulation of heavy metal in soil and water which leads to poor growth of plants. The heavy metal tolerance in bacteria may give the benefit to agricultural production in a contaminated site by enhancing plant growth promotion using various PGP traits (Tiwari $\boldsymbol{e t}$ al., 2018; Abedinzadeh et al., 2019). Endophytic bacterial isolates were tested against 11 heavy metals, out of that they showed the resistance against lead, magnesium, manganese, barium and aluminium. The bacterial isolates PR1, JB3 and JB6 were also able to grow well on high salt concentration and they showed growth up to $1.7 \mathrm{M} \mathrm{NaCl}$ concentration. About $20 \%$ of cultivable and $30 \%$ irrigated land is severely affected by salinity and increasing by $10 \%$ annually (Shrivastava and Kumar, 2015)

All the isolates used in the pot experiment showed the overall positive effect on plant growth. Total nitrogen content analyzed in aerial plant parts were found higher in comparison to the uninoculated control plants. In the previous studies, it has been demonstrated that nitrogen fixing organism enhance the plant growth upon inoculation (Patel et al., 2017). The plant growth promotion in terms of different plant growth parameter was compared with the uninoculated control plants. Agrobacterium sp. PR1 isolate showed to increase in dry weight of root significantly, whereas Pseudomonas sp. JB3 and Brevundimonas sp. JB6 significantly improve the shoot length and total nitrogen content in the aerial part of plants. The Agrobacterium sp. PR1 isolate showed the cross colonization in the wheat plant as the source of isolation was pearl-millet root part. The ability to colonize the plant parts were analyzed on nitrogen free medium and LB agar amended with respective antibiotic as obtain in antibiotic resistance test. In this study, antibiotic-resistance has been used for monitoring plant colonization by endophytic bacteria upon re-isolation during pot experiment.

To summarize, there were only a small number of potential nitrogen fixing endophytic bacteria found inside the plant tissue of wheat and pearl-millet plants of Anand, Gujarat, India. This study allows the identification of true nitrogen fixing bacteria to reside inside the internal tissue of root plants. The three strains isolated in this study improved the plant growth as well as total nitrogen content. Future studies will be focused on the analysis of these isolates at field level. 
Conflict of interest: The authors have no conflict of interest.

Acknowledgements: JKP is grateful to Dr. Datta Madamwar, UGC-BSR-Faculty Fellow, P G Department of Biosciences, Gujarat, India, for providing facilities for DNA sequencing.

\section{REFERENCES}

Abedinzadeh, M., Etesami, H., \& Alikhani, H. A. (2019). Characterization of rhizosphere and endophytic bacteria from roots of maize (Zea mays L.) plant irrigated with wastewater with biotechnological potential in agriculture. Biotechnology Reports, 21, e00305. https://doi.org/10.1016/j.btre.2019.e00305 Ahmad, F., Ahmad, I., \& Khan, M. S. (2008). Screening of free-living rhizospheric bacteria for their multiple plant growth promoting activities. $\begin{array}{llll}\text { Microbiological } & \text { research, } & 163(2), & 173-181\end{array}$ https://doi.org/10.1016/j.micres.2006.04.001

Altschul, S. F., Gish, W., Miller, W., Myers, E. W., \& Lipman, D. J. (1990) Basic local alignment search tool. Journal of molecular biology, 215(3), 403-410. https://doi.org/10.1016/S0022-2836(05)80360-2

Arshad, M., \& Frankenberger, W. T. (1991). Microbial production of plant hormones. In The rhizosphere and plant growth (pp. 327-334). Springer, Dordrecht.

Baldani, J. I., Baldani, V. L. D., Seldin, L., \& Döbereiner, J. (1986) Characterization of Herbaspirillum seropedicae gen. nov., sp. nov., a rootassociated nitrogen-fixing bacterium. International Journal of Systematic and Evolutionary Microbiology, 36(1), 86-93. https://doi.org/10.1099/00207713-36$1-86$

Chi, F., Shen, S. H., Cheng, H. P., Jing, Y. X., Yanni, Y. G., \& Dazzo, F. B (2005). Ascending migration of endophytic rhizobia, from roots to leaves, inside rice plants and assessment of benefits to rice growth physiology. Applied and environmental microbiology, 71(11), https://doi.org/7271-7278

10.1128/AEM.71.11.7271-7278.2005

Estrada, P., Mavingui, P., Cournoyer, B., Fontaine, F., Balandreau, J., \& Caballero-Mellado, J. (2002). A N2-fixing endophytic Burkholderia sp. associated with maize plants cultivated in Mexico. Canadian journal of microbiology, 48(4), 285-294. https://doi.org/10.1139/w02-023

Feng, Y., Shen, D., \& Song, W. (2006). Rice endophyte Pantoea agglomerans YS19 promotes host plant growth and affects allocations of host photosynthates Journal of applied microbiology, 100(5), 938-945. https://doi.org/10.1111/j.13652672.2006.02843.x

Gourmelon, V., Maggia, L., Powell, J. R., Gigante, S., Hortal, S., Gueunier, C., \& Carriconde, F. (2016). Environmental and geographical factors structure soil microbial diversity in New Caledonian ultramafic substrates: a metagenomic approach. PloS one, 11(12). https://doi.org/10.1371/journal.pone.0167405

Gyaneshwar, P., James, E. K., Mathan, N., Reddy, P. M., Reinhold-Hurek, B., \& Ladha, J. K. (2001). Endophytic colonization of rice by a diazotrophic strain of Serratia marcescens. Journal of bacteriology, 183(8), 2634-2645 https://doi.org/10.1128/JB.183.8.2634-2645.2001

Gyaneshwar, P., James, E. K., Mathan, N., Reddy, P. M., Reinhold-Hurek, B., \& Ladha, J. K. (2001). Endophytic colonization of rice by a diazotrophic strain of Serratia marcescens. Journal of bacteriology, 183(8), 2634-2645. DOI: 10.1128/JB.183.8.2634-2645.2001

Hardoim, P. R., Van Overbeek, L. S., Berg, G., Pirttilä, A. M., Compant, S., Campisano, A., \& Sessitsch, A. (2015). The hidden world within plants: ecological and evolutionary considerations for defining functioning of microbia endophytes. Microbiology and Molecular Biology Reviews, 79(3), 293-320. https://doi.org/10.1128/MMBR.00050-14

Holt, J.G., Krieg, N.R., Sneath, P.H.A., Stanley, J.T. and William, S.T. (1994 Bergey's Manual of Determinative Bacteriology. Williams and Wilikins, Baltimore, 786-788.

Ji, S. H., Gururani, M. A., \& Chun, S. C. (2014). Isolation and characterization of plant growth promoting endophytic diazotrophic bacteria from Korean rice $\begin{array}{llll}\text { cultivars. } & \text { Microbiological } & \text { research, } & 169(1),\end{array}$ https://doi.org/10.1016/j.micres.2013.06.003

Kumar, S., Stecher, G., Li, M., Knyaz, C., \& Tamura, K. (2018). MEGA X: molecular evolutionary genetics analysis across computing platforms. Molecular biology and evolution, 35(6), 1547-1549. https://doi.org/10.1093/molbev/msy096 Ladha, J. K., Barraquio, W. L., \& Revilla, L. (1997). Isolation of endophytic diazotrophic bacteria from wetland rice. In Opportunities for Biological Nitrogen Fixation in Rice and Other Non-Legumes (pp. 15-24). Springer, Dordrecht. Madhaiyan, M., Alex, T. H. H., Te Ngoh, S., Prithiviraj, B., \& Ji, L. (2015) Leaf-residing Methylobacterium species fix nitrogen and promote biomass and seed production in Jatropha curcas. Biotechnology for biofuels, 8(1), 222. https://doi.org/10.1186/s13068-015-0404-y

Madhaiyan, M., Saravanan, V. S., Jovi, D. B. S. S., Lee, H., Thenmozhi, R., Hari, K., \& Sa, T. (2004). Occurrence of Gluconacetobacter diazotrophicus in tropical and subtropical plants of Western Ghats, India. Microbiological research, 159(3), 233-243. https://doi.org/10.1016/j.micres.2004.04.001
Mareque, C., Taulé, C., Beracochea, M., \& Battistoni, F. (2015). Isolation, characterization and plant growth promotion effects of putative bacterial endophytes associated with sweet sorghum (Sorghum bicolor (L) Moench). Annals of microbiology, 65(2), 1057-1067. https://doi.org/10.1007/s13213-014 $\underline{0951-7}$

Meena, M., Swapnil, P., Zehra, A., Aamir, M., Dubey, M. K., Goutam, J., \& Upadhyay, R. S. (2017). Beneficial microbes for disease suppression and plant growth promotion. In Plant-Microbe Interactions in Agro-Ecological Perspectives (pp. 395-432). Springer, Singapore. https://doi.org/10.1007/978-981-10-6593416

Patel, J. K., \& Archana, G. (2017). Diverse culturable diazotrophic endophytic bacteria from Poaceae plants show cross-colonization and plant growth promotion in wheat. Plant and Soil, 417(1-2), 99-116. https://doi.org/10.1007/s11104-017-3244-7

Peng, G., Zhang, W., Luo, H., Xie, H., Lai, W., \& Tan, Z. (2009). Enterobacter oryzae sp. nov., a nitrogen-fixing bacterium isolated from the wild rice species Oryza latifolia. International journal of systematic and evolutionary microbiology, 59(7), 1650-1655. https://doi.org/10.1099/ijs.0.005967-0

Poly, F., Monrozier, L. J., \& Bally, R. (2001). Improvement in the RFLP procedure for studying the diversity of nifH genes in communities of nitrogen fixers in soil. Research in microbiology, 152(1), 95-103 https://doi.org/10.1016/S0923-2508(00)01172-4

Praeg, N., Pauli, H., \& Illmer, P. (2019). Microbial diversity in bulk and rhizosphere soil of Ranunculus glacialis along a high-alpine altitudinal gradient Frontiers in microbiology, 10, 1429. https://doi.org/10.3389/fmicb.2019.01429

Prakamhang, J., Minamisawa, K., Teamtaisong, K., Boonkerd, N., \& Teaumroong, N. (2009). The communities of endophytic diazotrophic bacteria in cultivated rice (Oryza sativa L.). Applied soil ecology, 42(2), 141-149. https://doi.org/10.1016/j.apsoil.2009.02.008

Prayitno, J., \& Rolfe, B. (2010). Characterization of endophytic diazotroph bacteria isolated from rice. HAYATI Journal of Biosciences, 17(2), 73-78 https://doi.org/10.4308/hjb.17.2.73

Puri, A., Padda, K. P., \& Chanway, C. P. (2018). Evidence of endophytic diazotrophic bacteria in lodgepole pine and hybrid white spruce trees growing in soils with different nutrient statuses in the West Chilcotin region of British Columbia, Canada. Forest Ecology and Management, 430, 558-565. https://doi.org/10.1016/j.foreco.2018.08.049

Reinhold-Hurek, B., \& Hurek, T. (1998). Life in grasses: diazotrophic

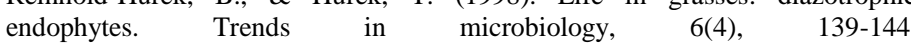
https://doi.org/10.1016/S0966-842X(98)01229-3

Reyes, I., Valery, A., \& Valduz, Z. (2007). Phosphate-solubilizing microorganisms isolated from rhizospheric and bulk soils of colonizer plants at an abandoned rock phosphate mine. In First international meeting on microbial phosphate solubilization (pp. 69-75). Springer, Dordrecht.

Richardson, A. E., Barea, J. M., McNeill, A. M., \& Prigent-Combaret, C. (2009) Acquisition of phosphorus and nitrogen in the rhizosphere and plant growth promotion by microorganisms. Plant and soil, 321(1-2), 305-339. https://doi.org/10.1007/s11104-009-9895-2

Rosenblueth, M., \& Martínez-Romero, E. (2006). Bacterial endophytes and their interactions with hosts. Molecular plant-microbe interactions, 19(8), 827-837. https://doi.org/10.1094/MPMI-19-0827

Sambrook, J., Fritsch, E. F., \& Maniatis, T. (1989). Molecular cloning: a laboratory manual (No. Ed. 3). Cold spring harbor laboratory press.

Santi, C., Bogusz, D., \& Franche, C. (2013). Biological nitrogen fixation in non-

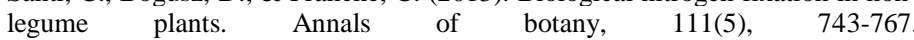
https://doi.org/10.1093/aob/mct048

Shrivastava, P., \& Kumar, R. (2015). Soil salinity: a serious environmental issue and plant growth promoting bacteria as one of the tools for its alleviation. Saudi journal of biological sciences, 22(2), 123-

131.https://doi.org/10.1016/j.sjbs.2014.12.001

Silveira da, A. P. D., Sala, V. M. R., Cardoso, E. J. B. N., Labanca, E. G., \& Cipriano, M. A. P. (2016). Nitrogen metabolism and growth of wheat plant under diazotrophic endophytic bacteria inoculation. Applied Soil Ecology, 107, 313 319. https://doi.org/10.1016/j.apsoil.2016.07.005

Solanki, M., Kundu, B. S., \& Nehra, K. (2018). Molecular diversity of phosphate solubilizing bacteria isolated from the rhizosphere of chickpea, mustard and wheat. Annals of Agrarian Science, 16(4), 458-463. https://doi.org/10.1016/j.aasci.2018.05.007

Tiwari, S., \& Lata, C. (2018). Heavy metal stress, signaling, and tolerance due to plant-associated microbes: an overview. Frontiers in plant science, 9, 452 https://doi.org/10.3389/fpls.2018.00452

Villegas, E., Ortega, E., \& Bauer, R. (1984). Chemical methods used at CIMMYT for determining protein quality in cereal grains (pp. 35-pages) CIMMYT.

Wang, Q., Garrity, G. M., Tiedje, J. M., \& Cole, J. R. (2007). Naive Bayesian classifier for rapid assignment of rRNA sequences into the new bacterial taxonomy. Applied Environmental Microbiology, 73(16), 5261-5267. https://doi.org/10.1128/AEM.00062-07 
Ward, M. H. (2009). Too much of a good thing? Nitrate from nitrogen fertilizers and cancer. Reviews on environmental health, 24(4), 357-363. https://doi.org/10.1515/reveh.2009.24.4.357

Yanni, Y. G., Rizk, R. Y., Corich, V., Squartini, A., Ninke, K., PhilipHollingsworth, S., \& Schmidt, T. M. (1997). Natural endophytic association between Rhizobium leguminosarum bv. trifolii and rice roots and assessment of its potential to promote rice growth. In Opportunities for Biological Nitrogen Fixation in Rice and Other Non-Legumes (pp. 99-114). Springer, Dordrecht https://doi.org/10.1023/A:1004269902246

Zhang, D., Spadaro, D., Valente, S., Garibaldi, A., \& Gullino, M. L. (2012).

Cloning, characterization, expression and antifungal activity of an alkaline serine protease of Aureobasidium pullulans PL5 involved in the biological control of postharvest pathogens. International journal of food microbiology, 153(3), 453464. https://doi.org/10.1016/j.ijfoodmicro.2011.12.016 